\title{
Physical and Microbial Quality of Broiler Chicken Meat Soaked in Syzygium polyanthum Infusion with Different Storage Time
}

\author{
Edi Suryanto ${ }^{1, *}$, Jamhari Jamhari ${ }^{1}$, Ulil Afidah ${ }^{1}$ and Nresnandira Aulia Utami ${ }^{1}$ \\ ${ }^{1}$ Department of Animal Products Technology, Animal Science Faculty, Universitas Gadjah Mada, Yogyakarta, \\ Indonesia \\ ${ }^{*}$ Corresponding author. Email: edi_ugm@ugm.ac.id
}

\begin{abstract}
Chicken meat is highly nutritious but also easily damaged. The aim of this study was to evaluate the soaking chicken meat effect in bay leaf (Syzygium polyanthum) infusion. Total of 30 chicken meat samples were soaked with infused bay leaf $(0 \%$ and $15 \%)$ for 30 minutes and different storage times $\left(0,2,4,6\right.$, and 8 days) at $4^{\circ} \mathrm{C}$. Physical characteristics ( $\mathrm{pH}$, cooking loss, and tenderness) and the total of microbial (Total Plate Count) were evaluated. Soaking and storage time did not affect the physical characteristics of chicken meat, but it could decrease the color value and increased the aroma value of raw meat, as well as the tenderness and aroma of cooked meat. The use of bay leaf infusion ( $S$. polyanthum) can minimized the total number of microbes in chicken meat during storage at refrigerator temperature. There was no interaction between storage time and infused concentration on the physical and sensory characteristics of chicken meat. It could be concluded that the use of $S$. polyanthum presented antibacterial against pathogenic microbes and improved the sensory quality of meat.
\end{abstract}

Keywords: Chicken meat, bay leaf, storage time, physical quality, total plate count.

\section{INTRODUCTION}

Chicken meat is one of as the most widely consumed animal proteins in various countries [1]. It is considered as relatively low cost and as a healthy alternative due to its low fat content, versatility [2], high nutrional value, and distinct flavor [3]. Perishable and vulnerable shelf life are disadvantage of fresh chicken meat [4]. In addition, the availability of nutritional value in meat, such as proteins, fat, free amino acids, mineral salts, vitamins and water content are factors that support the growth of microorganisms, especially during processing, storage, and distribution of chicken meat, both at the retail and consumer levels. [5]. Undesirable quality changes in chicken meat can occur due to these microorganisms, especially contamination caused by lactic acid bacteria as microorganisms that are closely related to meat spoilage [6]. There is an impact in the form of a financial burden that must be borne by the producer because of the damage to chicken meat. Therefore, the procedure for extending the shelf life of meat and its quality are urgently needed considering that meat spoilage is a major problem encountered in the meat processing industry [7].

Many synthetic preservatives in the food industry are used to suppress microbial growth and thereby extend the shelf life of meat, such as butyl hydroxylanisole (BHA), butyl hydroxyltoluene (BHT) and tertiary butylhydroquinone (THBQ) [8]. But on the other hand, the adverse effects of BHT, TBHQ, and BHA endanger human health, some of which are characterized by allergies, headaches, asthma, to dermatitis [9]. Recent study have been conducted on the utilization of natural antioxidant that indicates their capacity and safety [10]. The advantages of natural ingredients such as essential oils and plant extracts include the discovery of antimicrobial properties in them which intensive research has tested and found promising results [11]. These natural preservatives are contained in spices, which are rich in phenolic compounds as it can improve food quality by reducing lipid oxidation and microbial growth. [12].

These day, the useful substances such as antimicrobial and antioxidant in plants have been used 
to replace the synthetic preservatives [13], for example the use of Hyssop (Hyssopus officinalis L.) on the shelf life of ground beef [14]. Another useful plant as natural antioxidant is $S$. polyanthu, which is rich in phenolic compounds. $S$. polyanthum leaves contains the compound of triterpenoid, flavonoid, carbohydrate, saponin, tannin, alkaloid [15], and polyphenols [16], therefore it can plays a role as an antioxidant and antibacterial agent [17].

To our knowledge, there have been no studies that have tested the antioxidant and antimicrobial effects of $S$. polyanthum on the storage of raw chicken meat with variations in storage time. Summarizing the above explanation, this work aims to determine the effect of $S$. polyanthum on physical and microbial qualities.

\section{MATERIAL AND METHODS}

\subsection{Material}

Material. The materials used in this study consisted of 32 days old Lohman broiler chicken breast, bay leaf, distilled water, buffer solution ( $\mathrm{pH} 7$ and $\mathrm{pH} 4)$, Plate Count Agar (PCA), and buffered peptone water (BPW) $0,1 \%$.

\subsection{Methods}

Producing Bay Leaf Infusion. Salam or Indonesian bay leaves were obtained from traditional markets in Yogyakarta (Gendeng Market, Prambanan, Sleman, Yogyakarta, Indonesia). The infusion was made by extracting the simplicia of bay leaves with water at $90^{\circ} \mathrm{C}$ for 15 minutes [18]. The selected bay leaves in this study were dark green and leaves after the $3^{\text {rd }}$ leaf from the shoot. Production of bay leaf infusion was carried out in the following steps, the leaves of fresh bay were balanced using analytical weighing scales, trimmed to reduce the size, washed, placed in a pan, and then added distilled water according to the desired infusion concentration, then heated in a pan for $15 \mathrm{~min}$ at $90^{\circ} \mathrm{C}$. The production of bay leaf infusion refers to the Director General of Drug and Food Control, Republic of Indonesia (Dirjen POM RI) by weighing the bay leaves as needed. To produce $15 \%$ infusion, it takes $15 \mathrm{~g}$ of bay leaves then added by water to a volume of $100 \mathrm{~mL}$. Then the solution was filtered with a sterile cloth. The concentrations of the infusion made were $0 \%$ and $15 \%$.

The Preparation of Chicken Meat. The material used in this study was the breast meat of Lohman strain chicken aged 32 days (Royan Chicken Processing, Yogyakarta, Indonesia). A total of 30 samples of chicken meat were divided into 5 groups which were differentiated based on storage time $(0,2,4,6$, and 8 days). The chicken meats were then soaked in bay leaf infusion with the concentration of $0 \%$ and $15 \%$ for 30 minutes. The chicken meats were stored at a refrigerator temperature of $4^{\circ} \mathrm{C}$ with non-vacuum packaging.

pH Value Determination. To determine the $\mathrm{pH}$ of the sample, measurements were made with a laboratory pH-meter (Hi98107 Hanna Instrument) [19]. Minced meat weighing $2 \mathrm{~g}$ was homogenized in $18 \mathrm{~mL}$ of distilled water. The resulting slurry was measured the $\mathrm{pH}$ value using $\mathrm{pH}$-meter (accuracy $\pm 0.01 \mathrm{pH}$ units). For calibration of $\mathrm{pH}$ metter, 2 buffer solutions consisting of acid buffer $(\mathrm{pH}=4.00 \pm 0.05)$ and neutral buffer $(\mathrm{pH}=7.00 \pm 0.01)$ were performed. The $\mathrm{pH}$ value was then expressed as the average of the three determinations

Warner-Bratzler Shear Force (WSBF) Determination. The determination of WSBF was carried out with slight modifications [20]. At this stage, the prepared meat was placed in a vacuum plastic and then cooked in a water bath at $80^{\circ} \mathrm{C}$ until the inside temperature of water bath was $70^{\circ} \mathrm{C}$. The sample was then cut in the direction of the meat fiber where the cross-sectional size made was $1.5 \mathrm{~cm} \times 0.07 \mathrm{~cm}$ [21] Measurements were carried out 3 times at different places. The WSBF value in this case was calculated as the average reading for the core of the same steak. The tenderness value was expressed in $\mathrm{kg} / \mathrm{cm}^{2}$

Cooking Loss Determination. Chicken meats were trimmed towards fiber direction and weighed approximately $25 \mathrm{~g}$. They were placed into polyethylene plastic and vacuum packed with a vacuum machine. Cooking loss was determined with a little modification [21]. At this stage, the sample was poured directly into a water bath (the sample is still in a vacuum plastic at this time) at $60^{\circ} \mathrm{C}$ for 20 minutes. The temperature was then raised to $80^{\circ} \mathrm{C}$ and waited for 30 minutes. Absorbent paper was used to remove excess moisture before the sample is finally weighed. The result of this process was expressed as a percentage of weight loss compared to the initial weight [22]. Chicken meats were trimmed towards fiber direction and weighed approximately $25 \mathrm{~g}$ (x). They were cooled (thawed) in their sealed state with running water. They were removed from their polyethylene plastic then wiped with tissues and weighed their final weight.

$$
\begin{gathered}
\text { Cooking loss }(\%)=\frac{\mathrm{X}-\mathrm{Y}}{\mathrm{x}} \times 100 \% \\
\mathrm{X}=\text { Initial Weight } \\
\mathrm{Y}=\text { Final Weight }
\end{gathered}
$$

Total Bacteria. The bacteria test was determined with a little modification [23]. One gram of chicken meat was poured into a test tube containing $9 \mathrm{~mL}$ of sterile $0.1 \%$ buffered peptone water $(\mathrm{BPW})$ as a $10^{-1}$ dilution. Then $1 \mathrm{~mL}$ was taken and inserted into a test tube containing $9 \mathrm{~mL}$ of sterile $0.1 \% \mathrm{BPW}$ as a $10^{-2}$ dilution and so on until the $10^{-5}$ dilution. Then $1 \mathrm{~mL}$ was 
taken and planted in a petri dish containing plate count agar (PCA) media in duplicate with a dilution of $10^{-2}$, $10^{-3}$, and $10^{-4}$. Then incubated at a temperature of $34^{\circ} \mathrm{C}$ to $36^{\circ} \mathrm{C}$ for $24 \mathrm{~h}$. Count the number of colonies in each series of dilutions. Colonies counted were petri dishes with a total of 25 to 250 colonies [24].

\section{RESULT AND DISCUSSION}

\section{1. pH Value}

This study found that there was no significant effect of infused bay leaf and storage time on the $\mathrm{pH}$ value of chicken meat. In general, $\mathrm{pH}$ mean of chicken meat sample is presented in Table 1 . The mean $\mathrm{pH}$ value of $0 \%$ treatment is 5.86 , while $15 \%$ treatment is $\mathrm{pH} 5.73$.

Table 1. $\mathrm{pH}$ test results of chicken meat with the addition of bay leaf infusion at different storage

\begin{tabular}{|l|l|l|l|}
\hline \multirow{2}{*}{$\begin{array}{l}\text { Storage } \\
\text { time } \\
\text { (days) }\end{array}$} & \multicolumn{2}{|c|}{ Concentration $(\%)$} & \multirow{2}{*}{ Average } \\
\cline { 2 - 4 } & 0 & 15 & \\
\hline 0 & $5.95 \pm 0.16$ & $5.91 \pm 0.15$ & $5.93 \pm 0.12$ \\
\hline 2 & $5.71 \pm 0.30$ & $5.42 \pm 0.31$ & $5.56 \pm 0.12$ \\
\hline 4 & $5.73 \pm 0.28$ & $5.65 \pm 0.50$ & $5.69 \pm 0.12$ \\
\hline 6 & $5.94 \pm 0.22$ & $5.86 \pm 0.32$ & $5.90 \pm 0.12$ \\
\hline 8 & $5.96 \pm 0.21$ & $5.83 \pm 0.44$ & $5.89 \pm 0.12$ \\
\hline Average & $5.86 \pm 0.23$ & $5.73 \pm 0.36$ & \\
\hline
\end{tabular}

ns: non-significant

The $\mathrm{pH}$ value of two different treatments of chicken meat did not show a significant value. Both $\mathrm{pH}$ values in the treatment are still in the normal range of chicken meat. The normal $\mathrm{pH}$ after one-hour slaughtering is 6.9 to 7.1 and after $24 \mathrm{~h}$ slaughtering is almost 5.7 to 5.9 [25]. Chicken meat has a pH that tends to be almost the same as the $\mathrm{pH}$ of the bay leaf solution, which is in the range of 5.4 to 5.74 [26]. It was worth mentioning that chicken meat's $\mathrm{pH}$ might be also influenced by the $\mathrm{pH}$ of bay leaf infusion. The results of the study are in accordance with previous research conducted that the bay leaf solution had no significant effect on broiler chicken meat [27].

\subsection{Cooking Loss}

The result presented in Table 2 shows that the cooking loss increased during the storage time. Even so, the treatment given was found to have no significant effect ( $>>0.05)$ on cooking loss. Cooking losses for concentrations of 0 and $15 \%$ were $30.21 \%$ and $30.92 \%$, respectively. There was no significant difference in the cooking loss value due to the immersion treatment and storage time, possibly related to the $\mathrm{pH}$ value, which was also not significantly different. In other words, the factor that affects cooking loss is the $\mathrm{pH}$ value of the meat followed by the ability of the meat to bind water. [28]. The results of this study are in line with other research that stated that broiler chicken meat soaked in musk orange juice and stored at $-2^{\circ} \mathrm{C}$ to $4{ }^{\circ} \mathrm{C}$ did not give a significant difference to the value of chicken meat cooking losses [29].

Table 2. Cooking loss of chicken meat with the addition of bay leaf infusion at different storage times (\%)

\begin{tabular}{|l|l|l|l|}
\hline \multirow{2}{*}{$\begin{array}{l}\text { Storage } \\
\text { time } \\
\text { (days) }\end{array}$} & \multicolumn{2}{|l|}{ Concentration $(\%)$} & Average $^{\mathrm{ns}}$ \\
\cline { 2 - 4 } & 0 & 15 & \\
\hline 0 & $29.87 \pm 2,50$ & $32.15 \pm 2,11$ & $31.01 \pm 1.55$ \\
\hline 2 & $28.98 \pm 3.05$ & $27.18 \pm 5,50$ & $28.08 \pm 1.55$ \\
\hline 4 & $30.35 \pm 1.50$ & $30.58 \pm 2.81$ & $30.47 \pm 1.55$ \\
\hline 6 & $30.24 \pm 2.92$ & $32.42 \pm 6.36$ & $31.33 \pm 1.55$ \\
\hline 8 & $31.62 \pm 3.79$ & $30.92 \pm 4.47$ & $31.94 \pm 1.55$ \\
\hline Average & $30.21 \pm 2.57$ & $30.92 \pm 4.35$ & \\
\hline
\end{tabular}

ns: non-significant

The study revealed that storage at $4^{\circ} \mathrm{C}$ with different storage times also had no significant effect on meat cooking losses. This proves that chicken meat with a shelf life of up to eight days at $4^{\circ} \mathrm{C}$ is still in good condition.

\subsection{Tenderness}

Based on the data presented in Table 3, it was known that there was a significant effect of the treatment of soaking chicken meat on the tenderness value of broiler chickens. The statistical test showed that the immersion treatment using $15 \%$ bay leaf extract reduced the tenderness value by $18.13 \%(\mathrm{P}<0,05)$, from $3,97+1,52$ to $3,25+1,35$.

Table 3. The tenderness of chicken meat with the addition of bay leaf infusion at different storage times $\left(\mathrm{kg} / \mathrm{cm}^{2}\right)$

\begin{tabular}{|c|c|c|c|}
\hline \multirow{2}{*}{$\begin{array}{l}\text { Storage } \\
\text { time } \\
\text { (days) }\end{array}$} & \multicolumn{2}{|c|}{ Concentration } & \multirow[t]{2}{*}{ Average } \\
\hline & 0 & 15 & \\
\hline 0 & $6.40 \pm 0.31$ & $5.47 \pm 1.51$ & $5.93 \pm 0.32^{p}$ \\
\hline 2 & $3.96 \pm 1.23$ & $3.24 \pm 0.57$ & $3.60 \pm 0.32^{q}$ \\
\hline 4 & $3.88 \pm 0.75$ & $2.48 \pm 0.36$ & $3.18 \pm 0.32^{q}$ \\
\hline 6 & $2.74 \pm 0.36$ & $2.71 \pm 0.07$ & $2.73 \pm 0.32^{q}$ \\
\hline 8 & $2.85 \pm 0.91$ & $2.35 \pm 0.47$ & $2.60 \pm 0.32^{q}$ \\
\hline Average & $3.97 \pm 1.52^{\mathrm{a}}$ & $3.25 \pm 1.35^{b}$ & \\
\hline
\end{tabular}


Table 4. Total Plate Count (TPC) of chicken meat with the addition of bay leaf infusion at different storage times $(\log \mathrm{cfu} / \mathrm{g})$

\begin{tabular}{|c|c|c|c|c|c|c|}
\hline \multirow{2}{*}{$\begin{array}{l}\text { Concen } \\
\text { tration (\%) }\end{array}$} & \multicolumn{5}{|c|}{ Storage time (day) } & \multirow[t]{2}{*}{ Average } \\
\hline & 0 & 2 & 4 & 6 & 8 & \\
\hline 0 & $4.76 \pm 0.15$ & $5.14 \pm 0.44$ & $5.39 \pm 0.36$ & $5.95 \pm 0.18$ & $6.4 \pm 0.07$ & $5.53 \pm 0.65^{a}$ \\
\hline 15 & $4.52 \pm 0.07$ & $4.7 \pm 0.17$ & $5.22 \pm 0.12$ & $5.73 \pm 0.18$ & $6.3 \pm 0.12$ & $5.29 \pm 0.69^{b}$ \\
\hline Average & $4.64 \pm 0.17^{a}$ & $4.92 \pm 0.38^{b}$ & $5.3 \pm 0.26^{c}$ & $5.84 \pm 0.2^{d}$ & $6.35 \pm 0.11^{\mathrm{e}}$ & \\
\hline
\end{tabular}

p, q Values on different superscripts on the same line show significant differences $(\mathrm{P}<0.01)$

Soaking treatment for 2 days also reduced the meat tenderness value $(\mathrm{P}<0.05)$, from $5.93+0.32 \mathrm{~kg} / \mathrm{cm} 2$ to $3.60+0.32 \mathrm{~kg} / \mathrm{cm} 2$. However, further tests showed that there was no interaction between treatments on the variable value of meat tenderness. The mean value of tenderness of meat with $0 \%$ treatment was $3.97 \mathrm{~kg} / \mathrm{cm} 2$, while the $15 \%$ treatment was $3.25 \mathrm{~kg} / \mathrm{cm} 2$. The decrease in meat tenderness value was caused by the antioxidant and antibacterial content in the bay leaf extract, these compounds can act as a tenderizing agent with phenol content in the bay leaf infusion. The meat soaked in bay leaves infusion had a higher level of tenderness, presumably due to the antioxidant effect of bay leaf infusion on the calpain enzyme in chicken meat. The calpain enzyme is a proteolytic enzyme that plays a role in breaking certain peptide bonds, which causes the tenderness process at the beginning of postmortem [30]. This is consistent with research conducted by [21] namely the use of vitamin $\mathrm{E}$ as an antioxidant, can increase meat tenderness because vitamin $\mathrm{E}$ can protect the calpain enzyme from oxidation.

The second day of storing meat at $4{ }^{\circ} \mathrm{C}$ showed an increase in the tenderness value, this increase was due to the enzyme activity that occurred in the withering process. In the post-frying phase, the $\mathrm{pH}$ value has decreased, this is related to the tenderness of the meat. During a decrease in meat $\mathrm{pH}$, proteolytic enzyme activity occurs, namely the enzyme CANP (CalciumActivated Neutral Proteinase) and catepsin [31]. The CANP enzyme will be active at the beginning of the withering process around $\mathrm{pH} 6.5$ to 8.0 which functions to degrade myofibrils (actin and myosin). After the CANP enzyme works, then the catepsin enzyme is active and works in the range of 3.7 to 7.0 which functions to degrade myofibrils and collagen, thus causing the meat to become more tender.

\subsection{Total Plate Count}

The results in table 4 show that the total bacteria of chicken meat with immersion treatment and different storage times at refrigerator temperature had a significant effect. The mean total of meat with $0 \%$ treatment was $5.29 \log$ colony forming unit $(\mathrm{cfu}) / \mathrm{g}$, while $15 \%$ treatment was $5.53 \mathrm{log} \mathrm{cfu} / \mathrm{g}$. This shows that the bay leaves have good inhibitory power. The mean of total microbes in chicken meat increased with increasing storage time. The highest microbial total was reached on the 8th day, namely $6.35 \mathrm{log} \mathrm{cfu} / \mathrm{g}$. The number of MI microbial samples before storage at refrigerator temperature showed smaller results (4.52 $\log \mathrm{cfu} / \mathrm{g}$ ) than the control (4.76 $\log \mathrm{cfu} / \mathrm{g})$. This shows that bay leaves have inhibitory power because they contain tannins, flavonoids, and triterpenoids.

This acts as a change in membrane permeability, changes in numerous intracellular structures caused by hydrogen binding of phenolic compounds to enzymes [32]. As with phenols, flavonoids work as antimicrobials by binding to proteins through hydrogen bonds, resulting in damage to protein structure, disturbed cell wall instability, and cytoplasmic membranes. Disruption of cytoplasmic integrity causes the escape of macromolecules from ions so that cells lose their shape and become lysis [33].

\section{CONCLUSION}

In conclusion, soaking chicken meat in bay leaf infusion (S. polyanthum) with different storage time can increase the tenderness of chicken meat and inhibit microbial growth untuil $4^{\text {th }}$ day. However, bay leaf infusion did not give significant effect on the $\mathrm{pH}$ and cooking loss of chicken meat.

\section{AUTHORS' CONTRIBUTIONS}

Study conception and design ES, J; data collection: UA, NA; analysis and interpretation of results: ES, J, UA, and NA; draft manuscript and preparation: UA, and NA. All authors reviewed the results and approved te final version of manuscript.

\section{ACKNOWLEDGMENTS}

This work was supported by Department of Animal Products Technology, Animal Science Faculty, Universitas Gadjah Mada. 


\section{REFERENCES}

[1] OECD, "Meat consumption (indicator) (Publication no. 10.1787/fa290fd0-en)," 2019. https://data.oecd.org/agroutput/meatconsumption.htm (accessed Jul. 02, 2020).

[2] S. Tan, H. L. De Kock, G. Dykes, R. Coorey, and E. M. Buys, "Enhancement of poultry meat: Trends, nutritional profile, legislation and challenges," S. Afr. J. Anim. Sci., vol. 48, no. 8, pp. 199-212, 2018.

[3] J. H. Choe, K. C. Nam, S. O. Jung, B. N. Kim, H. J. Yun, and C. R. Jo., "Differences in the quality characteristics between commercial Korean native chickens and broilers," Korean J. Food Sci. Anim. Resour., vol. 30, pp. 13-19, 2010. DOI: $10.5851 /$ kosfa.2010.30.1.13

[4] C. Rukchon, A. Nopwinyuwong, S. Trevanich, T. Jinkarn, and P. Suppakul, "Development of a food spoilage indicator for monitoring freshness of skinless chicken breast," Talanta, vol. 130, pp. 547-554, 2014. https://doi.org/10.1016/j.talanta.2014.07.048

[5] V. Muchenje, K. Dzama, M. Chimonyo, P. Strydom, A. Hugo, and J. Raats, "Some biochemical aspects pertaining to beef eating quality and consumer health: A review," Food Chem., vol. 112, no. 2, pp. 279-289, 2009. https://doi.org/10.1016/j.foodchem.2008.05.103

[6] A. Doulgeraki, D. Ercolini, F. Villani, and G. E. Nychas, "Spoilage microbiota associated to the storage of raw meat in different conditions," Int. J. Food Microbiol., vol. 157, pp. 130-141, 2012.https://doi.org/10.1016/j.ijfoodmicro.2012. $\underline{05.020}$

[7] S. Petrou, M. Tsiraki, V. Giatrakou, and I. N. Savvaidis, "Chitosan dipping or oregano oil treatments, singly or combined on modifified atmosphere packaged chicken breast meat," Int. J. Food Microbiol., vol. 156, pp. 264-271, 2012. DOI: $10.1016 /$ j.ijfoodmicro.2012.04.002

[8] F. Artes, P. Gomez, and F. Artes-Hernandez, "Physical, physiological and microbial deterioration of minimally fresh processed fruits and vegetables," Food Sci. Technol. Int., vol. 13, pp. 177-188, 2007. https://doi.org/10.1177/1082013207079610

[9] M. Bondi, A. Lauokova, S. Niederhausern, P. Messi, and C. Papadopoulou, "Natural preservatives to improve food quality and safety," J. Food Qual., vol. 3, 2017. https://doi.org/10.1155/2017/1090932

[10] L. X. Zhang, Q. Deyong, C. H. Meng, and L. Ren, "Effect of mulberry leaf extracts on color, lipid oxidation, antioxidant enzyme activities and oxidative breakdown products of raw ground beef during refrigerated storage," $J$ Food Qual., 2016. Doi:10.1111/jfq.12187

[11] H. Sakkas, P. Gousia, V. Economou, V. Sakkas, S. Petsios, and C. Papadopoulou, "In vitro antimicrobial activity of five essential oils on multidrug resistant Gram-negative clinical isolates," J. Intercult. Ethnopharmacol., vol. 5, no. 3, pp. 212-218, 2016. DOI: $\underline{10.5455 / \text { jice. } 20160331064446}$

[12] H. H. Zhang, W. Jingjuan, and X. Guo, "Effects of antimicrobial and antioxidant activities of spice extracts on raw chicken meat quality," Food Sci. Hum. wellness, vol. 5, pp. 39-48, 2016.https://doi.org/10.1016/j.fshw.2015.11. $\underline{003}$

[13] B. MM, N. ME, S. Y, S. H, and H. LC, "PlantBased Phenolic Molecules as Natural Preservatives in Comminuted Meats: A Review," Antioxidants (Basel), vol. 10, no. 2, p. 263, 2021, doi: 10.3390/antiox10020263.

[14] M. Michalczyk, R. Macura, I. Tesarpwocz, and J. Banas, "Effect of adding essential oils of coriander (Coriandrum sativum L.) and Hyssop (Hyssopus officinalis L.) on the shelf life of ground beef," Meat Sci., vol. 90, pp. 842-850, 2012. DOI: $\underline{10.1016 / j . m e a t s c i .2011 .11 .026}$

[15] E. Agus, "Uji Fitikimia Dan Anti Bakteri Ekstrak Daun Salam (Syzygium polyanthum) Terhadap Bakteri Salmonella typhi Dan Escherichia coli Secara In Vitro," Mahakam Med. Lab. Technol. J., vol. 2, no. 1, pp. 1-9, 2017.

[16] M. D. Hidayati, T. Ersam, K. Shimizu, and S. Fatmawati, "Antioxidant activity of Syzygium polynthum extracts," Indones. J. Chem., vol. 17, no. 1, pp. 49-53, 2017. Doi: $\underline{10.22146 / \mathrm{ijc} .23545}$

[17] R. A. A. Lelono, S. Tachibana, and K. Itoh, "In vitro Antioxidative activities and polyphenol content of Eugenia Polyantha Weight Grown in Indonesia," Pakistan J. Biol. Sci., vol. 12, pp. 1564-1570, 2009. DOI: 10.3932/pjbs.2009.1564.1570

[18] G. Ariyanti, "Perbedaan Efektivitas Flavonoid Dan Taninekstrak Daun Salam Syzygium polyanthum [Wight] Walp Terhadap Daya Hambat Bakteri Enterococcus faecalis," Universitas Muhammadiyah Semarang, 2017.

[19] V. S. Kurcubic et al., "Antioxidant and antimicrobial activity of Kitabelia vitifolia extract as alternative to the added nitrite in fermented dry sausage," Meat Sci., vol. 97, pp. 456-467, 2014. 
[20] X. Luo, Y. Zhu, and G. H. Zhou, "Electron microscopy of contractile bands in low voltage electrical stimulation beef," Meat Sci., vol. 80, no. 3, pp. 948-951, 2008. DOI: $10.1016 /$ j.meatsci.2008.03.017

[21] Soeparno, Ilmu dan Teknologi Daging, 5th ed. Yogyakarta: Gadjah Mada University Press, 2015.

[22] K. O. Honikel, "Reference methods for the assessment of physical characteristics of meat," Meat Sci., vol. 49, no. 4, pp. 447-457, 1998. http://dx.doi.org/10.1016/S0309-1740(98) 00034-5

[23] D. Wulandari, R. Yuliatmo, and Sugiyanto, "The effect of coating of edible film from bovine split hide gelatin on beef meatballs properties," J. Indones. Trop. Anim. Agric., vol. 43, no. 2, pp. 177-183, 2018. DOI: https://doi.org/10.14710/jitaa.43.2.177$\underline{183}$

[24] Badan Standardisasi Nasional, Metode Pengujian Cemaran Mikroba dalam Daging, telur dan susu, serta hasil olahannya, SNI 2897. Jakarta: Badan Standardisasi Nasional, 2008.

[25] P. Haščík, I. Elimam, J. Garlík, M. Bobko, and J. Čuboň, "The effect of bee pollen as supplement dietary for meat $\mathrm{pH}$, cooling and freezing loses on broiler chickens meat," Anim. Welfare, Ethol. Hous. Syst. J., vol. 9, no. 3, pp. 477-482, 2013.

[26] E. A. Pura, K. Suradi, and L. L. Suryaningsih, "Pengaruh berbagai konsentrasi daun salam (Syzygium polyanthum) terhadap daya awet dan akseptabilitas pada karkas ayam broiler," J. Ilmu Ternak, vol. 15, pp. 37-38, 2015. DOI : https://doi.org/10.24198/jit.v15i2.9525

[27] M. Al-Hijazeen and M. M. Al-Rawasdesh, "Preservative effects of rosemary exctract (Rosmarinus officinalis L.) on quality and storage stability of chicken meat patties," Food Sci. Technol., vol. 39, no. 1, pp. 27-34, 2017. https://doi.org/10.1590/1678-457X.24817

[28] K. Suradi, "Perubahan sifat fisik daging ayam broiler post mortem selama penyimpanan temperatur ruang (change of physical characteristics of broiler chicken meat post mortem during room temperature storage)," $J$. Ilmu Ternak, vol. 6, no. 1, pp. 23-27, 2006. DOI : https://doi.org/10.24198/jit.v6i1.2261

[29] A. K. Y. Wowor, T. A. Ransaleleh, M. S. Tamasoleng, and Komansilan, "Lama penyimpanan pada suhu dingin broiler yang diberi air perasan jeruk kasturi (Citrus madurensisi Lour.)," J. Zootek, vol. 30, no. 2, pp.
DOI:http://doi.org/10.35792/zot.2.2014.598 0

[30] G. A. Teye and I. Okutu, "effect of ageing under tropical conditions on the eating qualities of beef," African J. food Agric. Nutr. Dev., vol. 9, no. 9, pp. 1902-1913, 2009.

[31] S. E. Harris, S. M. Lonergan, W. R. Jones, and D. Rankins, "Antioxidant status affects color stability and tenderness of calcium chlorideinjected beef," J. Anim. Sci., vol. 79, pp. 666677, 2014. DOI: $\underline{10.2527 / 2001.793666 x}$

[32] T. T. Cushnie and A. J. Lamb, "Recent advances in understanding the antibacterial properties of flavonoids," Int. J. Antimicrob. Agents, vol. 38, pp. 99-107, 2011. DOI: $\underline{10.1016 / \text { j.ijantimicag.2011.02.014 }}$

[33] O. J., T. Suzuki, P. Gasaluck, and G. Eumkeb, "Antimicrobial properties and action of galangal (Alpinia galanga Linn.) on Staphylococcus aureus," Food Sci. Technol., vol. 39, pp. 12141220 , 2006. https://doi.org/10.1016/j.lwt.2005.06.015 